\title{
Exploring indoor climate and comfort effects in refurbished multi-family dwellings with improved energy performance
}

\author{
Linn Liu $^{1}$, Josefin Thoresson ${ }^{2}$ \\ ${ }^{1}$ Division of Energy Systems, Department of Management and Engineering, Linköping University, Sweden \\ linn.liu@liu.se. ${ }^{2}$ Department of Thematic Studies - Technology and Social Change, Linköping University, \\ Sweden.
}

\begin{abstract}
The building stock in Sweden includes many older residential dwellings often with inadequate building envelopes and poor insulation resulting in high energy use and uncomfortable indoor climate. Improving energy performance in multi-family dwellings by refurbishment processes is the key factor to success in order to meet national and European energy goals to reduce energy use in the building sector by $50 \%$ through 2050 . How is indoor environment affected when dwellings are refurbished to become low-energy dwellings? This paper aims to explore parameters for indoor climate and comfort in refurbished dwellings transformed into low-energy dwellings from an inter-disciplinary perspective, taking into account both quantitative and qualitative aspects of indoor climate using technical measurements, a questionnaire survey, and qualitative interviews. Based on a combination of methods, the results show that the indoor climate has largely been improved and user satisfaction was high in the refurbished dwellings. Results also showed that however indoor temperatures were too high during summer, resulting in dissatisfaction from residents. Overheating can be prevented by providing information to the residents about the functionality of the heating system and by adding shade in front of the windows.
\end{abstract}

\section{Introduction}

There is considerable pressure to improve the energy system and to reduce the energy demand in the building sector (Nässén \& Holmberg, 2005). In Sweden, buildings are responsible for almost $40 \%$ of primary energy utilization. Reducing energy use in residential buildings is the key factor to success in order to meet national energy targets to reduce energy demand and energy use in the building sector by 50\% through 2050 (Swedish Energy Agency, 2012). The European Commission directive on Energy Performance of Buildings also takes up this issue and claims that the housing sector has the largest potential to decrease the demand side for energy (Directive 2010/31/EU).

The building stock in Sweden includes many older multi-family dwellings from 1950-1985. According to statistics from the Swedish National Board of Housing, Building and Planning (2012) and SCB (2012), there are about 165,000 multi-family buildings of a total of 2,100,000 buildings of various types in Sweden. $57 \%$ of multifamily buildings were built from 1961-1985 and in virtually the same way from an architectural point of view. The most common facade material for these multi-family buildings is brick. The roofs are often covered with concrete roof tile. Exhaust ventilation systems are the dominant ventilation system. These buildings often have inadequate building envelopes and poor insulation and facade $U$ values were in general $0.38-0.4 \mathrm{~W} / \mathrm{m}^{2} \mathrm{~K}$ and 2.0 $2.2 \mathrm{~W} / \mathrm{m}^{2} \mathrm{~K}$ for windows of multi-family buildings from 1961-1985. Refurbishments in order to improve these deficits are necessary in order to lower energy demand. However, refurbishments result in both improved energy performance and thermal comfort in the dwellings. Refurbishments that convert old residential buildings into low-energy buildings but still provide a good living environment for the tenants are an important target (Power, 2008). So far refurbishments of older residential buildings have only been done on a small scale in Sweden. The function of dwellings in low-energy refurbished residential buildings has hardly been studied. A study of a refurbished building into passive house standard has however indicated deficits of uneven temperatures between floors of a three-story house (Jansson, 2010). However, what influence the outcome on the indoor environment in low-energy buildings has mainly been studied in newly built low-energy buildings (Hauge et al., 2010; Isaksson \& Karlsson, 2006).

This paper aims to explore parameters affecting indoor climate and comfort in dwellings refurbished to become low-energy dwellings with an improved energy performance by about $50 \%$. An interdisciplinary sociotechnical approach combining several data collection methods has been used for the study. This is based on the fact that the building forms an energy system composed of both technical elements and social aspects such as the members of the construction team and the residents living in the building. They are key actors for the 
performance of residential buildings (c.f. Rohracher, 2001). The following section will present perspectives on indoor comfort and climate in buildings and the study object. Then the different methods are presented, followed by a presentation of the results and a discussion and comparison of the methods used.

\section{Indoor comfort and environment in low-energy buildings}

Indoor comfort and environment is more than temperature alone and can be defined by temperature, humidity, light, and sound. Thermal environment is one part of the indoor climate (Isaksson \& Karlsson, 2006). To get a good indoor climate, the Swedish National Board of Health and Welfare recommends that the indoor temperature should not exceed $24^{\circ} \mathrm{C}$ during wintertime and $26^{\circ} \mathrm{C}$ during summertime and not go beyond $18^{\circ} \mathrm{C}$ (Socialstyrelsen, 2005), while the Forum for Energy Efficient Buildings (FEBY) does not recommend indoor temperatures that exceed $26^{\circ} \mathrm{C}$ for more than $10 \%$ of the time during summer (FEBY, 2009). However, it is important to discuss the meaning of a good indoor climate and how to create one. A distinction can be made between the concept of good comfort as something universal where there is an optimum temperature, and the opinion that the perception of good comfort is shaped by history and society, meaning that a desirable temperature involves the socio-cultural context and predominant conventions (Chappels \& Shove, 2005; Shove, 2003). That can explain why there are always some people who are dissatisfied with their indoor temperature, even if it is seemingly at a recommended level. Studies of satisfaction with indoor climate in new energyefficient buildings have also shown a discrepancy between measurements of indoor temperature and the residents' opinion about the temperature. Measured temperatures were often higher than was experienced by the residents, which points toward subjectivity in experiences between different residents (Isaksson \& Karlsson, 2006; Hauge et al., 2010).

\section{The study objects}

The objects for the study are buildings located in a residential area centrally located in the city of Linköping, Sweden. The area consists of six individual multi-family buildings with approximately 100 dwellings and a large multi-family building with 186 dwellings. All buildings in the area were designed by the same architect and constructed during 1979-80 in similar ways. Due to mold damage and poorly functioning technical systems, one tower-block building, Föreningsgatan 23 (F 23) was refurbished into a low-energy building during 2008-2009. F 23 contains 19 dwellings on six floors. Two dwellings in the building have been used as study objects for technical measurements. Before the refurbishment F 23 was a par with the other buildings in the area with similar features, like most multi-family buildings built from 1961-1985. The buildings used district heating for heating and a mechanical exhaust air ventilation system for ventilating. The dwellings are flats for rent and the residents do not purchase or own their dwellings.

The refurbishment resulted in the construction of a new facade and the roof was insulated. The windows were replaced to triple glazed windows with $\mathrm{U}$-value of $1.1 \mathrm{~W} / \mathrm{m}^{2} \mathrm{~K}$. A heat recovering exchanger (HRX) ventilation system was installed with a heat recovery efficiency of about $80 \%$. The building still uses district heating for heating. The new exterior wall includes a drain slot which makes it possible to add about $30 \mathrm{~cm}$ of insulation. The seal is located $8 \mathrm{~cm}$ outwards from the inside. Table 2 shows a comparison between the construction of the building before and after renovation.

\begin{tabular}{lll}
\hline & Before renovation & After renovation \\
\hline Facade & $\mathrm{U}$ was $0.21 \mathrm{~W} / \mathrm{m}^{2} \mathrm{~K}$ & $\mathrm{U}_{\text {ave }}$ is $0.15 \mathrm{~W} / \mathrm{m}^{2} \mathrm{~K}$ \\
Floor & $0.2 \mathrm{~m}$ cement $\mathrm{U}=3.4 \mathrm{~W} / \mathrm{m}^{2} \mathrm{~K}$ & $0.2 \mathrm{~m}$ cement $\mathrm{U}=3.4 \mathrm{~W} / \mathrm{m}^{2} \mathrm{~K}$ \\
Roof & $\mathrm{U}_{\text {tot }} 0.13 \mathrm{~W} / \mathrm{m}^{2} \mathrm{~K}$ & $\mathrm{U}_{\text {tot }} 0.17 \mathrm{~W} / \mathrm{m}^{2} \mathrm{~K}$ \\
Window & Dubble-glazed, $\mathrm{U}: 1.8 \mathrm{~W} / \mathrm{m}^{2} \mathrm{~K}$ & Triple-glazed $\mathrm{U}: 1.1 \mathrm{~W} / \mathrm{m}^{2} \mathrm{~K}$ \\
Thermal bridges & $\psi_{\text {ave }} 0.13 \mathrm{~W} / \mathrm{m} \mathrm{K}$ & $\psi_{\text {ave }} 0.1 \mathrm{~W} / \mathrm{m} \mathrm{K}$ \\
& & \\
\hline
\end{tabular}

Table 1. Comparison of U values of F23 before and after renovation.

F 23 had no individual energy meter before the refurbishment but energy use was estimated by dividing the total heating demand of all the buildings in the area. The heating area of F 23 is $2192 \mathrm{~m}^{2}$. The building's annual heating demand before refurbishment was estimated at about $245 \mathrm{MWh}$, which is equal to $131 \mathrm{kWh} / \mathrm{m}^{2}$. In 2011 
the annual heating demand was reduced to $147 \mathrm{MWh}$ which is equal to $67 \mathrm{kWh} / \mathrm{m}^{2}$ as shown by the energy meter.

\section{Method design}

The paper originates from a case study. Within the case study methodology a number of data collection techniques can be used (Yin, 1994). Indoor comfort and climate in buildings are depending on both the social context and technical potentials which are inseparable and can provide a better understanding of parameters affecting indoor climate and comfort (Rohracher, 2001). A characteristic combination of interdisciplinary methodologies in studying indoor comfort and climate has been used for this study combining a quantitative and qualitative approach from both a technical and a social point of view (cf. Isaksson \& Karlsson, 2006; Karlsson \& Moshfegh, 2007). Measurements of the thermal comfort from two dwellings have been used as input in BES software in order to simulate and calculate the energy use and indoor climate of the study object. Similar parameters which have influence on the indoor climate have been investigated by using a survey with the title "My indoor climate." The results of the survey do not have to be the same as the results from measurements and simulations (cf. Hauge et al., 2010; Isaksson \& Karlsson, 2006; Jansson, 2010). Good indoor comfort and how to achieve it can largely be related to interests and concepts in the construction process (Chappells \& Shove, 2005). Qualitative interviews have been conducted with the project team in the refurbishment process in order to study the planning and construction process. The interviews answer questions about reasons for the outcome affecting the results of measurements and residents' experience of the indoor climate.

The interdisciplinary approach in this study has several advantages. First, a similar approach for studying indoor environment in low-energy buildings has seldom been used. The users of the building and their perceptions and activities in the building are important for energy use and the indoor environment in low-energy buildings (Karlsson et al., 2007), but there are few studies focusing on end-user perspectives and experiences of indoor climate. Studies of indoor comfort often only have a technical perspective, focusing on technologies for improved energy performance in buildings (Rohdin et al., 2011). This study used questionnaires as a method for studying resident experiences of their indoor environment. There are studies using questionnaire surveys study indoor environment (Frontczak et al. 2012; Yoshino et al., 2012; Farrja et al., 2010), but few papers have used physical measurements combined with questionnaire methods (Tiberiu \& Vlad, 2012; Dahlan et al., 2011) where the focus is indoor climate. There are a few examples of studies studying users' satisfaction with the indoor climate combining technical measurements with resident interviews (Isaksson \& Karlsson, 2006; Karlsson \& Moshfegh, 2007). This study also comprises interviews but with project team participants. Research following organization of construction projects is rare (Rohdin et al., 2011), even if studies exploring construction teams' intentions are considered important (Hamza \& Greenwood, 2009). A second advantage is that combining and comparing these methods can reveal other discoveries, problems and consequences than if the methods were used and analyzed separately. The following presentation gives a closer description of each method used.

\subsection{Technical measurements and BES}

Technical measurements of parameters affecting the indoor climate have been conducted from two dwellings in the studied building F 23. These measurements were carried out during May and June 2011. Each measurement period lasted for 11 days. The measurements included indoor climate measurements (indoor temperature, $\mathrm{CO}_{2}$ concentration, air flow, humidity) and electricity consumption on a building level and on a household level. Predicted mean vote (PMV), and predicted percentage of dissatisfied (PPD) as two important indoor climate factors have been calculated from collected data from the measurements. The collected data have also been used as input in the simulation software IDA ICE 4.0, which has mainly been used for testing the indoor climate in this project. A Building Energy Simulation (BES) tool models the buildings' heating, cooling, ventilation, lighting, and other energy systems. There are several other energy simulation programs available, for example DEROB-LTH, Energy Plus, ESP-r and TRNSYS. IDA Indoor Climate and Energy 4.0 (IDA ICE 4.0) is one type of building energy simulation tool developed especially for indoor climate and energy design tasks. It accurately models the building construction and its control systems. Local weather climate profile, position of the building, material data, thermal bridges and air change rate are the basic inputs which are required by the program. A modeled building is based on many different zones. There is also more required input data such as indoor temperature, material construction, internal energy from the tenants and electrical equipment, and air flow if the building uses a mechanical ventilation system. By means of IDA ICE 4.0, heating, ventilating and air conditioning (HVAC) systems in the building can be modeled using mass flow networks or plant networks. 
(Thollander \& Rohdin, 2011). The output data includes detailed lowest possible energy consumption and best possible occupant comfort. With help of a detailed and dynamic multi-zone simulation the study of thermal indoor climate and energy use of the entire building can be approached (EQUA, 2012).

The two dwellings were modeled and simulated in IDA ICE 4.0. Apartment A is on the second floor and heating area is $76 \mathrm{~m}^{2}$. Apartment B is a double-story apartment which is on the top two floors; the heating area is $120 \mathrm{~m}^{2}$. The supply air flows and exhaust air flows of the measured apartments are in the range of 5-16 1/s and 10-20 1/s. A high value of exhaust air flow is required on account of the laundry rooms in each apartment. Heat losses $\varphi$ from thermal bridges which have been used as input data are different for different types of thermal bridges and vary from $0.05-0.15 \mathrm{~W} / \mathrm{m} \mathrm{K}$. All the other input data such as internal heat releases from the electrical appliances and human activities have been obtained from measurements and standardized values. A measurement instrument Innova ${ }^{1}$ was placed in the living room of each apartment. Clo-and met-value are two input data for Innova which is supposed to represent real people. $\mathrm{Clo}^{2}$-value should be set to 1.0 and met $^{3}$-value should be set to 1.2 which represents a person wearing ordinary indoor clothing, and is in dormant form (Warfvinge, 2000). All the parameters measured by Innova such as indoor temperature, air flow and indoor humidity, are used as input in calculations of PMV(Percentage Mean Value) and PPD (Predicted Percentage Dissatisfied), which are two indexes normally used together to calculate the percentage of a large number of people who are dissatisfied with the thermal indoor climate.

Two climate files of Linköping have been used for the simulation, one for 2011 and the other for a normal year. The average temperature of Linköping during 2011 was $7.3^{\circ} \mathrm{C}$ and for a normal year it is $7{ }^{\circ} \mathrm{C}$.

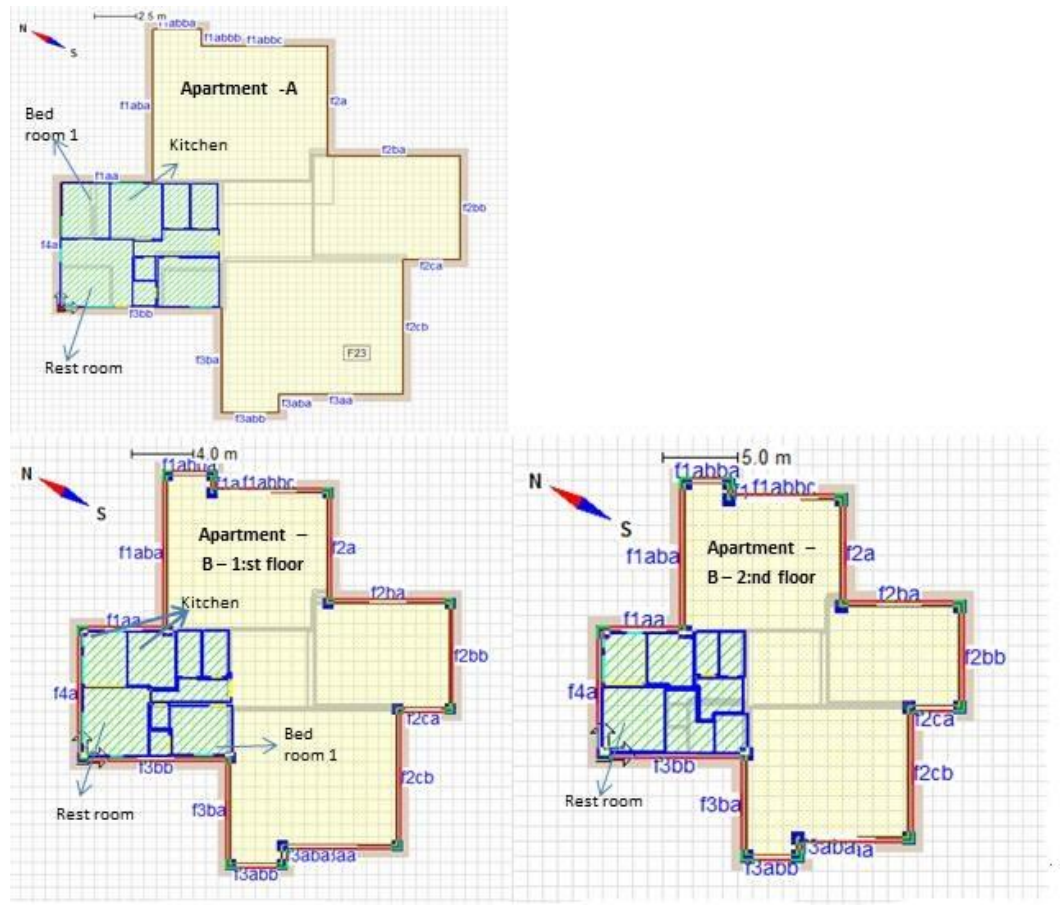

Fig 1 Apartment A \& B modeled by IDA ICE 4.0

Figure 1 shows 2D pictures of apartment A and B by using of the simulation software. Figure 3 shows the results of temperature variations in the simulated apartments.

During the measurement, some of the Tinny loggers which are used for temperature measurements stopped when their memories were full. Therefore the time steps on the $\mathrm{x}$-axis are different in picture $\mathrm{b}$ and $\mathrm{e}$ from other pictures below. Since the measurements started at different times, for apartment A the measurements started at 12:00 a.m. and for apartment B it started at 2:00 p.m., the x-axis therefore started with different times in the pictures in figure 2 below. Since there are no registered values of the heat demand by individual apartment, the

\footnotetext{
${ }^{1}$ Innova: A instrument which measures two indoor climate indexes in particular: PMV and PPD. PMV and PPD are based on indoor temperature, air velocity, and air humidity values which are collected by Innova.

${ }^{2}$ Clo: cloth thermal resistance. 1 clo corresponds $0.155^{\circ} \mathrm{Cm} 2 / \mathrm{W}$.

${ }^{3}$ Met: heat generating value. 1 met=60 W/skin area.
} 
validation could only be carried out by comparing the measured indoor temperatures with the simulated indoor temperatures in those rooms where the residents spend most of their time.
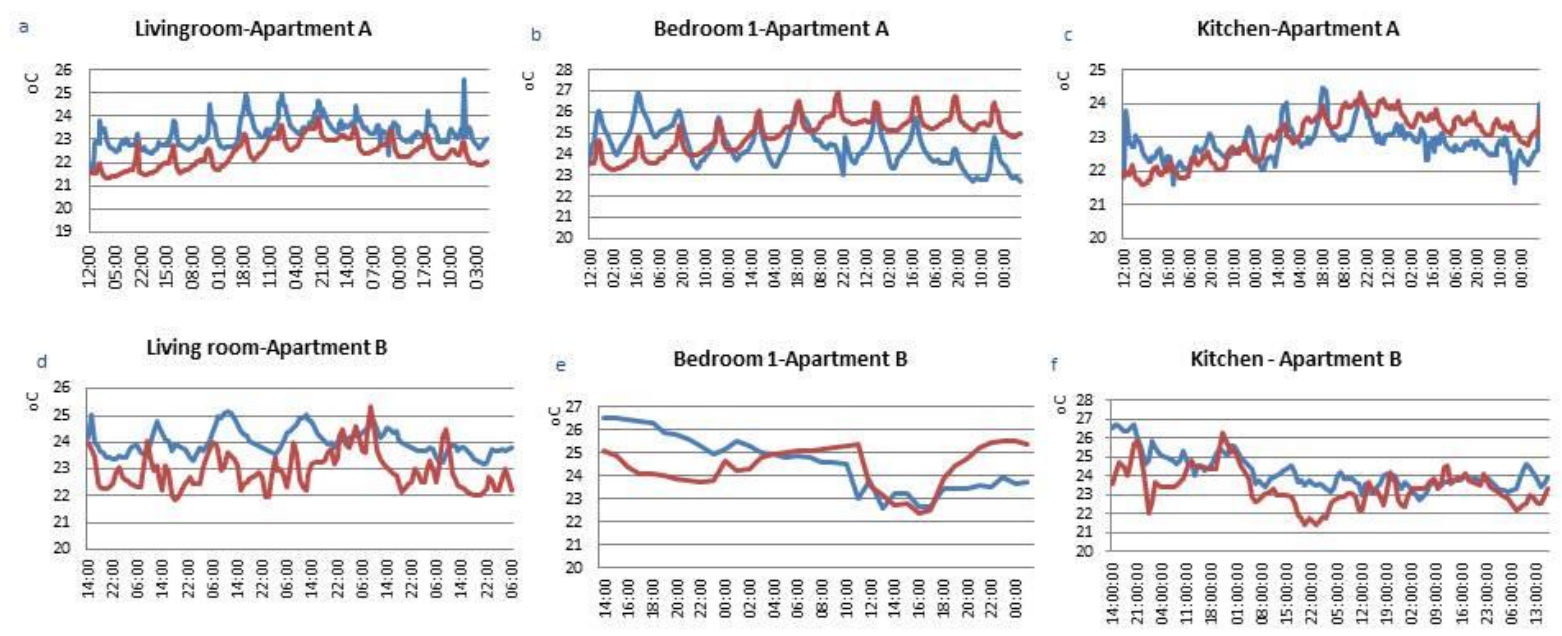

- Measurementoc - IDAOC

Fig 2. Validation of temperatures in different rooms from apartment A.

A mean deviation of the validation is about $2^{\circ} \mathrm{C}$. The deviations in the validation of the building model are due to several factors. The first one is the that climate file of the year 2011 used as input data during validation was created manually. Solar radiation was one of the six terms that were included in the climate file. The values of solar radiation were gathered from a STRANG model ${ }^{4}$. The STRANG model allows a deviation of solar radiation up to $12.9 \%$. The second deviation concerns measured temperatures. During the measurement period, temperature loggers may have inadvertently been moved, which would make the recorded temperature data insufficiently comprehensive. The last factor is human behavior and activities which may affect the simulation results to differ from reality. People with different habits regarding energy use can lead to higher or lower internal loads which in turn will affect the indoor temperature and the heat demand. Since the model is based on only two apartments, the simulation results cannot be generated as the situation of the whole building's indoor climate.

\subsection{Questionnaire survey}

A questionnaire has been used and sent out to residents in the whole area in order to get more generalized results of how residents from both refurbished and non-refurbished dwellings experience their indoor climate. The questionnaire method does not require actual contact with the respondent and is a widely used method to collect data from a large number of respondents, as in this case (Bryman, 2004). A pre-printed, standardized questionnaire was used called "My indoor climate." which is based on the so-called "Örebro model" (Örebro model, 2012) to study opinions about the indoor climate. The questionnaire includes five categories: the environment, air quality, noise situation, indoor temperature and residents' complaints. The questions were mainly closed questions where the residents could rank their experience of their indoor environment and did not include matters of why and how. If the research design does not demand too many open questions and has few follow-up questions, or includes "how" and "why" questions, a questionnaire is a suitable choice of method for studying user experiences (Thollander, 2011). In total, 80 questionnaires were distributed to the tenants in F 23 and to tenants living in non-renovated buildings in the neighborhood, of which 42 tenants chose to respond to the survey including 11 from $\mathrm{F} 23$. This represents a total response rate of 53\%, which seems acceptable. The data collected from the questionnaire are used in order to analyze the data qualitatively and no statistical analyses using a software tool have been done from the data (Bryman, 2004).

\footnotetext{
${ }^{4}$ STRANG model system measures include global radiation, photosynthetic active radiation, ultraviolet radiation (CIE weighted), direct radiation along with the sun duration of a horizontal resolution of approximately $11 \mathrm{x} 11 \mathrm{~km}$ in one hour. STRANG covers Scandinavia's geographic area and operated at SMHI. (SMHI, 2012) Information on direct solar radiation and global radiation from the radiation network of SMHI has been used for the validation of our model.
} 


\subsection{Qualitative interviews}

Ten qualitative in-depth interviews with project members on the refurbishment team including employees of the property owner and the construction company were conducted for the study. The employees were construction engineers, plant engineers, energy and environmental managers and contact persons for the residents. The interviewees were all connected to the refurbishment project. The aim of the interviews was to explore experiences and thoughts affecting the construction process and the outcome of the refurbishment. Conducted interviews lasted about one hour and were recorded and transcribed. The questions followed an interview template but took a semi-structured form. The questions were based on issues as to why the refurbishment was done in certain ways, which provided the opportunity to ask follow-up questions. That made the interview method useful in this case (Yin, 2007). The interviews have been interpreted and analyzed by searching for how events and processes are described concerning the refurbishment process.

\section{Results from the measurements and simulations}

The results from the measurements collected by the output from Innova which are the PMV and PPD indexes as shown in Table 2.

\begin{tabular}{lccc}
\hline & Temperature variation ${ }^{\circ} \mathrm{C}$ & PMV & PPD \\
\hline Apartment A & $21.60 \sim 25.40$ & $-0.6 \sim-0.4$ & $12 \sim 9 \%$ \\
Apartment B & $23.10 \sim 25.30$ & $-0.5 \sim-0.4$ & $11 \sim 9 \%$ \\
\hline Table 2. Indoor temperature and PMV PPD as measured data.
\end{tabular}

Table 2. Indoor temperature and PMV PPD as measured data.

In Sweden ISO $7730^{5}$ is used as an indoor comfort standard. According to ISO 7730 an acceptable indoor climate is when the PMV is between -0.5 to 0.5 , which corresponds to a PPD below $10 \%$ (ISO 7730, 2005). The measurement results of PMV and PPD in Table 2 also meet ISO 7730 requirements (ISO 7730, 2005) for a standard and acceptable indoor climate. Table 3 shows the simulated results of three selected rooms in each apartment where the households spent most of their time.

\begin{tabular}{lllc}
\hline Föreningsgatan 23 & $\begin{array}{l}\text { Temperature } \\
\text { variation }\end{array}$ & PMV & PPD \\
\hline Apartment A-Bedroom2 & $21{ }^{\circ} \mathrm{C} \sim 25^{\circ} \mathrm{C}$ & $0.3 \sim 0.6$ & $7 \sim 12 \%$ \\
Apartment B-Bedroom1 & $22.5{ }^{\circ} \mathrm{C} \sim 26.5^{\circ} \mathrm{C}$ & $0.5 \sim 0.7$ & $10 \sim 17 \%$ \\
Apartment A-Living room & $21{ }^{\circ} \mathrm{C} \sim 25^{\circ} \mathrm{C}$ & $0.3 \sim 0.5$ & $7 \sim 10 \%$ \\
Apartment B- Living room & $23.5{ }^{\circ} \mathrm{C} \sim 25{ }^{\circ} \mathrm{C}$ & $0.4 \sim 0.5$ & $9 \sim 10 \%$ \\
Apartment A-Kitchen & $21{ }^{\circ} \mathrm{C} \sim 27^{\circ} \mathrm{C}$ & $0.3 \sim 0.8$ & $7 \sim 20 \%$ \\
Apartment B-Kitchen & $22.8^{\circ} \mathrm{C} \sim 26.8{ }^{\circ} \mathrm{C}$ & $0.6 \sim 0.8$ & $12 \sim 20 \%$ \\
\hline
\end{tabular}

Table 3. Indoor temperature and PMV and PPD as simulated data.

The PMV and PPD from the simulated results of each apartment's restroom match with the measurements. The minus sign from Table 2 is due to the errors made by calibrating too low values of the clo- and met-value in Innova. This gave a wrong perception that the residents experienced a colder climate than they actually do.

Table 3 also shows that apartment $\mathrm{B}$ has higher indoor temperatures than apartment $\mathrm{A}$. When the indoor temperature in bedroom 1 of apartment $\mathrm{B}$ achieves almost $27^{\circ} \mathrm{C}$ the corresponding PMV is equal to 0.7 , which represents a warm indoor temperature. This is because the bedroom receives afternoon sunlight as it is situated at the west side of the building. Another reason is that apartment B is on the top floor and receives more sunlight than apartment A. However, simulation results indicate that there is a good indoor environment and they fulfill ISO 7730's requirements for a good indoor climate.

\footnotetext{
${ }^{5}$ ISO 7730: Ergonomics of the thermal environment -- Analytical determination and interpretation of thermal comfort using calculation of the PMV and PPD indices and local thermal comfort criteria
} 


\section{Questionnaire survey results}

The answers from the questionnaire survey are presented and divided between residents in the refurbished building F23, and residents living in non-refurbished dwellings in the same area. Figure 4 presents residents' experience of problems related to their indoor air quality.

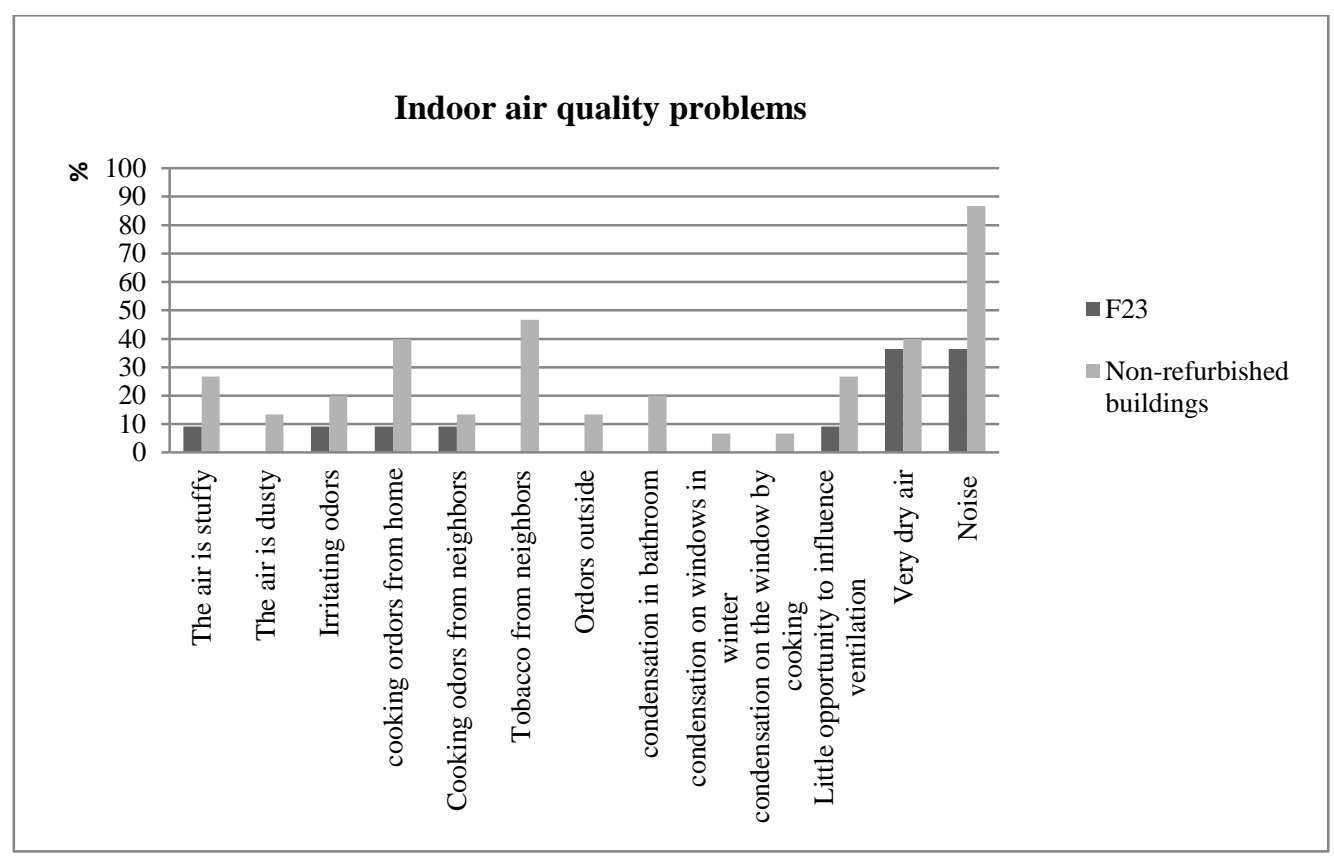

Fig 3. Indoor air quality problems

Residents from F 23 are more satisfied with the indoor air quality than residents from non-refurbished buildings in all aspects surveyed. Few residents in F 23 complained about unpleasant smells from the ventilation channel compared to $20-45 \%$ of the residents from the non-refurbished buildings. $20 \%$ of the residents in nonrefurbished buildings complained about residual moisture in the bathroom after showers. That problem was not experienced in F23. Condensation is a common problem in old buildings and a sign of the buildings poor air tightness. As the non-renovated buildings use mechanical air ventilation system, the supply air temperature is the same as the outdoor air temperature and the air is not preheated or filtered, which might explain the dissatisfaction about stuffy and dusty air in non-refurbished dwellings and not in F 23. However, the problem of dry air is comparable in F 23 and in non-refurbished dwellings. Regular maintenance of ducts, fans and registers are necessary in order to get functioning air ventilation and efficient fans (Swedish Energy Agency, 2012). Only one resident in F 23 complained about cooking odor or other unpleasant smells from their neighbors compared to $40 \%$ in non-refurbished buildings. Odor problem had been a problem in F23 after renovation but was solved when the property owner installed a filter in the ventilation channel. Unpleasant noise was experienced as a problem in both F 23 and non-refurbished dwellings but was considered a bigger problem in non-refurbished dwellings. A well-insulated building can also keep out a higher degree of unpleasant noise.

Figure 5 presents experiences concerning indoor air temperature problems. According to the simulation results, the indoor temperatures in the two dwellings can vary from $21{ }^{\circ} \mathrm{C}$ to above $27{ }^{\circ} \mathrm{C}$ (see Table 3) which exceeds the recommended indoor temperature (Socialstyrelsen 2005). 18\% of the residents in F 23 also experience problems with a high indoor temperature during summer compared to only $9 \%$ in non-refurbished dwellings. A well-insulated building is in need of less heating and the problem with overheating can be caused by the high temperature of the supply air from the ventilation system. 


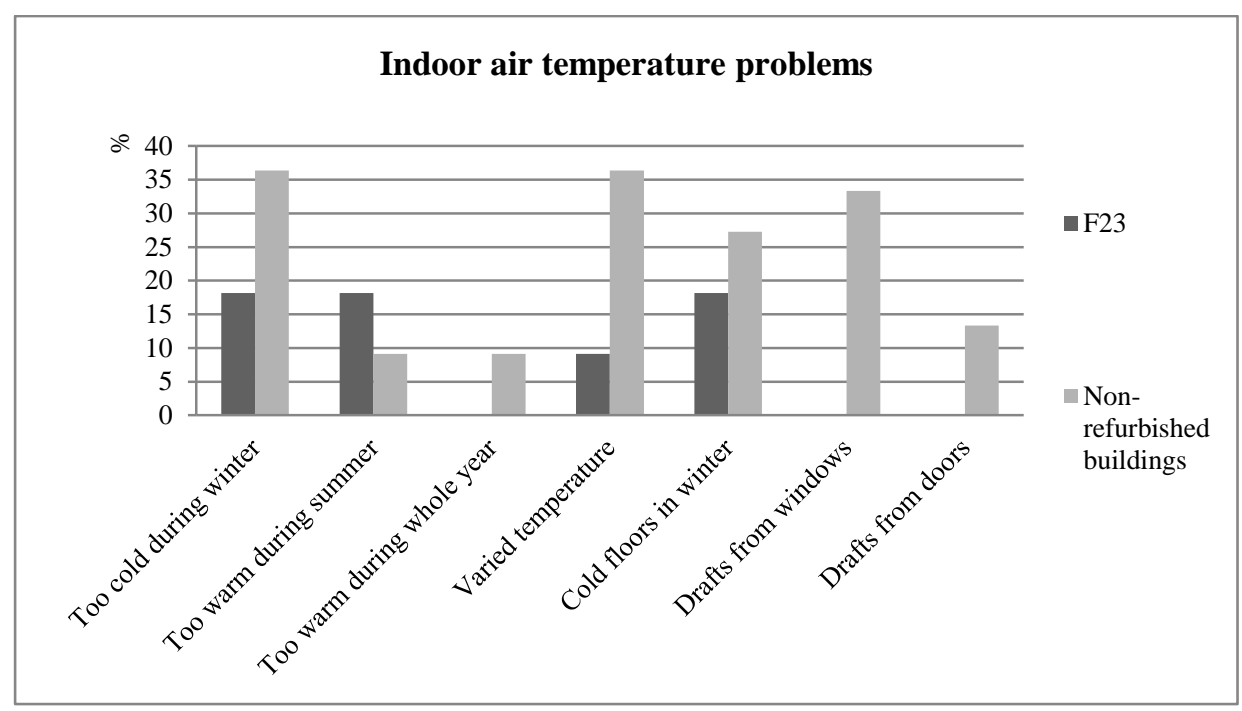

Fig 4. Indoor air temperature problems.

The heating elements in F23 turn off automatically when the indoor temperature drops to $14^{\circ} \mathrm{C}$, otherwise the internal heat and the HRX system will cover the temperature difference in order to keep the indoor temperature at $21^{\circ} \mathrm{C}$. Except for high indoor temperature during summer, residents in F 23 were more satisfied with their indoor temperature compared to residents in non-refurbished dwellings. A uniform indoor temperature is related to well-insulated walls, windows with a low U-value, an HRX system and no cold bridges removed during the refurbishment. Buildings with thermal bridges and poor insulation in walls and in windows can lose much heat through leakages, cool down indoor air and cause cold drafts. These problems were also experienced in nonrefurbished dwellings. No extra insulation was added to the floors in F 23 during the refurbishment which might explain why $18 \%$ of the residents experiences cold floors during wintertime.

\section{Results from the interviews}

The members of the refurbishment project team all had the opinion that the refurbishment of $\mathrm{F} 23$ was an energy project. The well-known goal among all interviewees was to improve energy performance by around 50\% to meet new energy goals and standards for buildings, and to meet perceived societal pressure to reduce energy use in buildings. The impression in the project team was that the residents were mostly positive about the refurbishment. Some residents questioned the extent of measures taken to reduce energy demand. A side benefit with building airtight and installing a ventilation system with a heat recovering exchanger (HRX) in order to reduce energy demand might be improved indoor comfort and climate according to some project team members. However that was seldom discussed in the interviews nor was residents informed of this by the project team. The indoor environment was mentioned by one interviewee as a change from the refurbishment that affects the residents in a positive way.

"The residents are hopefully affected in a positive way because the indoor environment should be more uniform. Less draft and in particular with the ventilation. They will now get preheated fresh air that will result in less draft and a better indoor environment."

Indoor comfort and climate issues were however only discussed by the interviewees to a small extent, and there were no measureable goals regarding indoor comfort or climate in the refurbishment process.

The energy goal should be reached by installing energy saving technologies that the project team had already tested in earlier projects. The choice of well-known technologies was due to the fact that the project team did not want to take any risks in testing new technologies for heating and ventilation. They only implemented measures that they believed the management team could handle. An example was the choice of windows. There were affordable windows on the market with even better energy performance. These windows were not installed since there had been condensation on the outside of the windows in earlier projects that resulted in complaints from residents. The construction team was also given a day of training where they learned the importance of building airtight and installing the technologies in order to get a low-energy demand for heat in the building. The aim was to reduce air leakages resulting in a lower use of energy for heating. The residents in refurbished dwellings were not given any information about installed technologies or how they should act in order for the system to work properly and function in an optimal way. The idea was that installed technologies in connection with the refurbishment were meant to be invisible and simple for the residents, and not affect their daily life. 
The installed energy-saving technologies were supposed to be unnoticed by the residents, who were not expected to contribute to lower the energy demand by changing their energy use. There should not be any changes for the residents to live in a refurbished energy-efficient dwelling from before the refurbishment according to the project members. However, one project member admitted that the installed thermostat was not adjustable to the same extent by the residents and turned off the heat more often after the refurbishment. That could result in residents experiencing a lower indoor temperature than actual temperature, depending on the resident. The interviewee also expressed apprehensions about differences in residents' perceptions of their indoor climate.

"There is... how shall I put it... a bit of psychology in how you perceive the indoor temperature."

The thermostat was not adjustable by the residents either. This was acknowledged by a couple of team members who thought some residents might not be accustomed with the fact that they cannot regulate the thermostat by themselves according to their needs, as they could do to some extent before the refurbishment.

"Before you get used to it you might perceive it as... very strange and you can perceive it as very

hard to not be able to directly affect the indoor temperature."

Another example of trials for invisible technologies was the seal in the insulation that was located $8 \mathrm{~cm}$ outwards from the inside. The residents can then drill up to $8 \mathrm{~cm}$ in the wall before they damage the seal, according to a member of the project team. The residents were however provided with very limited information about the seal and how far they could drill in the walls.

\section{Discussion}

There were no major differences between the technical measurements of the indoor climate, the residents' experience of the indoor climate, and the expectations on improvements to the indoor climate by several members in the project team. Overall the measured parameters of the indoor climate indicated that it should be an acceptable indoor climate that fulfills ISO 7730's requirements for a good indoor climate. The simulated PMV and PPD values from the measurements in the two dwellings indicated that the residents should be satisfied with the indoor temperature most of the time. The questionnaire also confirmed that residents in F23 in general were more pleased with their indoor climate than residents in non-refurbished buildings. The residents were however overall more satisfied with the temperature in their dwellings in the refurbished building, except for the indoor temperature during summertime. Rooms with windows directed to the south also had an indoor temperature exceeding recommended levels during summer. The measured values indicated a warm indoor temperature but not to the extent that the questionnaire results indicated the point of discrepancy between measured parameters and the residents' experience (cf. Hauge et al., 2010; Isaksson \& Karlsson, 2006; Jansson, 2010). High indoor temperatures have been a problem in buildings refurbished to low-energy buildings (cf. Jansson, 2010). There might be problems other than unsatisfied residents that go along with a high indoor temperature in low-energy buildings. A fast-growing trend is the demand for air-conditioning (cf. Chappels \& Shove, 2005). Even if it still is far from being a normal standard in dwellings in Sweden, it is more and more becoming a domestic standard in for example the UK and may become a demanded standard also in Sweden. A potential risk with low-energy buildings, with the aim to reduce energy demand, is that a high indoor temperature during summer can increase the demands for air-conditioning, which can eat up the energy saving potential with the energy-efficient building.

An interesting note is that the project team did not plan for or choose technologies for improving the indoor climate. The intention from the project team was not to deliver any specific comfort conditions. The idea was that technical measures, such as building airtight and providing mechanical heat exchange ventilation systems, should increase the energy efficiency. The meaning of good comfort and how that could be delivered was not specified in the project. However, a few team members anticipated that a low-energy refurbishment should result in a better indoor comfort but without a specification of what that would entail. Parts of the project team were aware that not all residents have the same opinion about what a good indoor climate is, but this knowledge was not used in the design of the refurbishment. The installed technical systems were chosen only with the intention to be invisible and not adjustable to the needs and understanding of the individual resident. That was based on an understanding that comfort for the residents is simplicity. The residents should not have to deal with the installed technical equipment temperature and ventilation, or know how to handle it. The residents however expressed a higher satisfaction about their indoor climate in the refurbished dwellings, but that does not answer whether they are pleased with the supposed invisible technical systems in their dwellings or not. The dwellings in the refurbished building overall got higher ratings in the questionnaire regarding the indoor climate than the dwellings in similar non-refurbished dwellings. That can also depend on other factors as there were mold problems in the non-refurbished buildings which might have had an effect on the questionnaire results. 
The project team carefully chose technologies they knew how to handle. They also made sure of that by providing training to the construction team in order to install the technologies properly, because some technologies might be new to them. To provide both written and oral information and instructions to the residents about the functionality of the technical systems in low-energy buildings and how they work, has been deemed crucial in order for the residents to know how to avoid indoor comfort problems (Mlecnik et al., 2012; Isaksson \& Karlsson 2006). The residents were however not given any information from the project team about the functionality of the ventilation system and their indoor temperature, even if the technologies also were new to them. Information about the function of the technical systems can potentially avoid problems with nonfunctioning systems such as high indoor temperature. To inform the residents that it is possible to call maintenance to lower the supply curve of heat when they perceive the indoor temperature as too warm instead of simply opening the windows and letting out heat may produce a more uniform indoor climate and save energy.

\section{Conclusions}

This study combines results from technical measurements and simulations from two dwellings, qualitative interviews with the project team, and a questionnaire survey covering the residents' experiences of their indoor climate. This socio-technical approach provides a larger picture of the thermal comfort in a low-energy refurbished building with dwellings with an improved energy performance by $50 \%$. Further studies need to include measurements and simulations on the building level too and more in-depth studies of resident experiences. Continuing refurbishments into low-energy dwellings need to take several aspects into account. The outcomes from this study indicate that the residents were more satisfied with their refurbished dwelling compared to non-refurbished dwellings, but information about the functionality of the technical system should be improved in order to keep a low-energy demand and to avoid high indoor temperatures. Information that a lowenergy refurbishment can also result in a better indoor environment should also be provided to the residents in order to avoid complaints about the extent of a low-energy refurbishment. The results show that it is important to be aware of the high indoor temperatures during summertime. A suggestion of a way to avoid overheating and maintain low-energy demand is to add shade in front of the windows in order to obtain a lower indoor temperature during summertime. Another suggestion is to lower the indoor temperature during summertime by adjusting the predetermined supply air's temperature in the HRX system from $21^{\circ} \mathrm{C}$ to $20^{\circ} \mathrm{C}$ during summer.

\section{References}

Bryman, A.: Social Research Methods. Oxford, Oxford University Press (2001)

Swedish National Board of Housing, Building and Planning.: Så mår våra hus. http://www.boverket.se/Bygga--forvalta/samar-vara-hus/ . Accessed 20 June 2012

Catalina, T.: Iordache, V.: IEQ assessment on schools in the design stage. Building and Environment. 49, 129-140 (2012)

Chappells, H.: Shove, E.: Debating the future of comfort: environmental sustainability, energy consumption and the indoor environment. Building, Research \& Information. 33:1, 32-40 (2005)

Dahlan. N.D.: Jones. P.J.: Alexander. D.K.: Operative temperature and thermal sensation assessments in non-air-conditioned multi-story hostels in Malaysia. Building and Environment. 46, 457-467 (2011)

Directive 2010/31/EU of the European Parliament and of the Council of 19 May 2010 on the energy performance of buildings, 18.6.2010, Official Journal of the European Union 153 (13) (2010)

Al-ajmi, D.F: Loveday, D.L.: Indoor thermal conditions and thermal comfort in air-conditioned domestic buildings in the dry desert climate of Kuwait. Building and Environment. 45:3, 704-710 (2010)

FEBY: Kravspecifikation för minienergihus. LTH rapport EBD-R--09/26, IVL rapport nr A1593, ATON rapport 0903. http://www.energieffektivabyggnader.se/download/18.712fb31f12497ed09a58000141/Kravspecifikation_Minienergihus_ver sion_2009_oktober.pdf (2009) Accessed 25 February 2012

Frontczak. M.: Andersen R. V.: Wargocki. P.: Questionnaire survey on factors influencing comfort with indoor environmental quality in Danish housing. Building and Environment. 50, 56-64 (2012) 
Hamza, N.: Greenwood, D.: Energy conservation regulations: Impacts on design and procurement of low-energy buildings. Building and environment. 44: 5, 929-936 (2009)

Hauge, Å.L.: Thomsen, J.: Berker, T.: User evaluations of energy efficient buildings: Literature review and further research. Proceedings of Renewable Energy Conference 2010, Trondheim, Norway. 97-108 (2010)

Isaksson, C.; Karlsson, F.: Indoor climate in low-energy houses - an interdisciplinary investigation. Building and Environment. 41:12, 1678-1690 (2006)

Jansson, U.: Passive houses in Sweden. From design to evaluation of four demonstration projects. Lund: Department of Architecture and Built Environment. EBD-T--10/12 (2010)

Karlsson, F.: Moshfegh, B.: Energy demand and indoor climate in a low-energy building-changed control strategies and boundary conditions. Energy and Buildings 38:4, 315-326 (2006)

Karlsson, F.: Moshfegh, B.:A comprehensive investigation of a low-energy building in Sweden. Renewable Energy. 32:11, 1830-1841 (2007)

Karlsson, F.:, Rohdin, P.: Persson, M-L.: Measured and predicted energy demand of a low-energy building: Important aspects when using building energy simulation. Building Services Engineering Research and Technology. 28:3, 223-235 (2007)

Mlecnik, E.: Schütze, T.: Jansen, S.J.T.: de Vries, G.: Visscher, H.J.: van Hal, A.: End-user experiences in nearly zero-energy houses. Energy and Buildings 49, 471-478 (2012)

Nässén, J.: Holmberg, J.: Energy efficiency — a forgotten goal in the Swedish Building sector? Energy Policy. 33:8, 1037$1051(2005)$

Power, A.: Does demolition or refurbishment of old and inefficient homes help to increase our environmental, social and economic viability? Energy Policy 36:12, 4487-4501 (2008)

Rohdin, P.: Glad, W.: Palm, J.: Low-energy buildings - scientific trends and developments. In: Palm, J. (ed.) Energy Efficiency, pp. 103-124. InTech, ISBN: 978-953-307-137-4 (2011)

Rohracher, H.: Managing the technological transition to sustainable construction of buildings: A socio-technical perspective. Technology Analysis \& Strategic Management. 13:1, 137-150 (2001)

SMHI: Sweden's Meteorological and Hydrological Institute - http://strang.smhi.se/ . Accessed 26th June 2012

Socialstyrelsen.: Temperaturer inomhus. ISBN: 91-7201-972-7 (2005)

Shove, E.: Comfort, Cleanliness and Convenience: The social organization of normality. Berg, Oxford (2003)

Statistics Sweden (SCB).: Statistics of multi-family buildings 2010, (2010)

Swedish Energy Agency.: Energy Mode 2012. Swedish Energy Agency, Eskilstuna (2012)

Thollander, P.: Questionnaires. In : Karlsson et al. (eds.) Interdisciplinary energy system methodology, pp 85-88. Division of Energy Systems, Linköping University (2011)

Thollander, P.: Rohdin, P.:Case study research. In : Karlsson et al. (eds.) Interdisciplinary energy system methodology, pp 12-16. Division of Energy Systems, Linköping University (2011)

Warfvinge, C.: Installationsteknik AK för V. Studentlitteratur, Lund (2000)

Yin, R.K.: Fallstudier: design och genomförande. Liber, Malmö (2007)

Yoshino. H, Guan. S. Lun. Y.F, Mochida. A., Shigeno. T., Yoshino. Y., Zhang. Q.Y.: Indoor thermal environment of urban residential buildings in China: winter investigation in five major cities. Energy and Buildings 36, 1227-1233 (2004)

Örebro model: Indoor climate problems - http://www.inomhusklimatproblem.se/index.html . Accessed 27th June 2012 
Dear Dr. Littlewood,

Thank you very much for the valuable options about our paper. We have made changes to the paper according to the requirements of the reviewers including commentaries how these changes satisfy these requirements.

\section{Review 1}

Page 4. Results from interviews. This should be the objective of the refurbishment and description of it and also the role of residents

Answer: More results from interview have been added. The results from the interviews on page 4 has been changed in order to include the objective with the refurbishment and a description of the objectives with issues of indoor climate and comfort in the refurbishment process. The roles the project team assesses to the residents in the refurbishment process are also added in the presentation of the results.

Page 7 Change ?110kWh/m2 of the first year? to ?110kWh/m2 in the first year?

Answer: We have changed the presentation of the numbers according to the requirements and moved them to section 3 , and present them in a more logical way in order to show the changes in energy performance.

Page 8 Change ?which also fill ISO 7730?s requirement? to ?which also fulfill ISO 7730?s requirement? Answer: Changes have been made in according to the requirements, and in order to explain the ISO requirements of indoor comfort standard and why these are compared to our results and resulted in that our results are in line with the requirements of the standard.

Page 9 Change figure number to 5

Page 10 Change figure number to 6

Answer: We have changed numbers of the figures.

\section{Review 2}

1.Reformat the paper to meet the Springer guidelines for paper format at SEB12, also ensuring that figures and tables are presented as requested.

Answer: The format of the paper has been adjusted to the Springer guidelines and is using the Springer format. The figures and tables are changed in order to meet requests.

2. The first paragraph on page one, should be entitled ?Abstract?.

Answer: The first paragraph on page 1 has been changed and is now entitled Abstract.

3. There are substantial results presented, which are interesting to the reader. However, there is no discussion section. Can the authors reformat some of their discussion in the results section, so that it is paced within a discussion section? In addition, the conclusions should then be written as conclusions to the entire paper and not include a discussion element.

Answer: The construction of the paper has been changed which is seems more logical. The discussion part and conclusion part have been re-written as separated parts. More interesting and important problems which we have found during the project have been emphasized in the discussion part. In the conclusion part, only conclusions from the entire paper are presented.

4. Please check your grammar and spelling in English;

Answer: The paper has been rewritten and the grammar and spelling have been proof read.

5. Ensure the list of references follows the Harvard and Springer protocols accurately.

Answer: The reference list have been changed according to the Springer protocols.

Yours sincerely

Linn Liu \& Josefin Thoresson

$28 / 06 / 12$ 